\title{
EVALUASI PENERAPAN PSAK 30 TENTANG SEWA PEMBIAYAAN KONSUMEN PADA ASTRA CREDIT COMPANIES (ACC) DI MANADO
}

\author{
Fajriah Gani ${ }^{1}$, Ventje Ilat $^{2}$,Victorina Z. Tirayoh ${ }^{3}$ \\ ${ }^{1,2,3}$ Jurusan Akuntansi, Fakultas Ekonomi dan Bisnis, Universitas Sam Ratulangi, Jl. Kampus Unsrat, Manado, \\ 95115, Indonesia \\ E-mail : fs.latief@yahoo.com
}

\begin{abstract}
The emergence of leasing agency is an attractive for enterpreneurs Because today they tend to use cash rupiah fund for operational, activites of the company. Through leasing they could obtain funds to finance the purchase of capital goods with a repayment period of between three to five years or more. The object of this research is Astra Credit Companise which is the largest auto finance company in Indonesia. The purpose of this research is to analyze the accounting treatment of leasing and reporting on Astra Credit Companaise in Manado. The method used is descriptive method, to identify the data that is used in connection with the assets that will be in the leasing of vehicles, identify the system of recording and reporting of leasing transactions, evaluating the advantages / disadvantages in accounting for leasing transactions and reporting of leasing transactions, as well as draw conclusions. The results of the research can be in the know that leasing has several types and classifications as well as the criteria for determining the accounting system. The accounting treatment and reporting of leasing transactions on Astra Credit Companaise using leasse capital system where the lease can be transferred ownership at the end of the lease term. Based Recording aspect, reporting and disclosure, the accounting treatment of leasing at Astra Credit Companaise in accordance with SFAS applicabl.
\end{abstract}

Keywords : Application of consumer finance lease, PSAK No.30

\section{PENDAHULUAN}

Dana memegang peranan penting dalam menunjang kegiatan operasional perusahaan. Perusahaan dapat mengggunakan data tersebut sebagai alat investasi melalui penanaman barang modal. Dana yang diterima oleh perusahaan digunakan untuk membeli aktiva tetap, untuk memproduksi barang dan jasa membeli bahan-bahan untuk berkepentingan produksi dan penjualan, dan lain-lain.

Dalam hal pengadaan barang modal, ada beberapa alternatif pembiayaan yang bisa dilakukan oleh perusahaan. Pembiyaan dari sumber internal dan pembiayaan dari sumber eksternal. Pembiayaan dari sumber internal dihasilkan sendiri di dalam perusahaan, diantaranya adalaah laba ditahan, modal saham, dan lain-lain. Sedangkan pembiayaan sumber eksternal berasal dari luar perusahaan, diantaranya adalah pinjaman bank, sewa guna usaha (leasing), penjualan kredit dari pemasok, dan lain-lain. Sebelum diterbitkannya Standar Akuntansi Keuangan No. 30 tentang Sewa (revisi 2011) oleh IAI, perusahaan di Indonesia yang bergerak di pembiayaan peralatan/barang modal melakukan transaksi penjualan, dengan cara leasing yang menggunakan Standar Akuntansi Keuangan No. 30 (revisi 2007).

Leasing di Indonesia sebenarnya masih relative baru dibandingkan dengan negara maju, yakni pertama kali diperkenalkan pada tahun 1974. Industri leasing muncul ditandai dengan diterbitkannya Surat Keputusan Bersama Menteri Keuangan, Menteri Perindustrian dan Menteri perdagangan Republik Indonesia tanggal 7 Februari 1974 tentang Perizinan Usahan Leasing. Pada saat ini, Dewan Standar Akuntansi Keuangan telah menyetujui exposure draft PSAK 30 (revisi 2011) tentang sewa dalam rapatnya pada tanggal 28 Juni 
2011 untuk disebar luaskan dan ditanggapi oleh perusahaan, regulator, perguruan tinggi, pengurus dan anggota IAI, dan pihak lainnya.

Dewasa ini, industri sewa semakin berkembang terlihat dari banyaknya pihak-pihak yang mendirikan lembaga pembiayaan di Indonesia, baik berbentuk BUMN, swasta nasional, Joint Venture bahkan perusahaan asing. Perkembangannya begitu pesat ini dapat dilihat pada awal tahun 80-an berjumlah 5 buah, terus meningkat dalam 10 tahun menjadi 115 buah perusahaan sewa dan akhir akhir ini mulai tahun 2000 usaha sewa menjadi salah satu bidang usaha yang sangat diminati. Sebagai perusahaan yang bergerak dalam pembiayaan, perusahaan harus berhati hati dalam mengolah asset yang dimiliki karena mengingat begitu beragamnya jenis pelayanan yang ditawarkan kepada konsumen sesuai dengan kebutuhan dan pembiayaannya, maka perusahaan dituntut untuk lebih professional dalam menerapkan kebijakan akuntansi dan pelaporannya dengan baik sehingga perusahaan dapat terus maju dan siap bersaing dengan perusahaan sejenis.

Astra Credit Companies adalah perusahaan yang bergerak di bidang pembiayaan. Perusahaan ini melakukan program vendor lease, yang mana melibatkan distributor otomotif biasa juga disebut dealer. Dalam hal ini yang bertindak sebagai dealer antara lain Hasjrat Abadi Toyota, Astra Daihatsu, Astra isuzu, serta Honda dan Nissan. ACC juga menjalankan perusahaan anjak piutang (factoring company) sebagai badan usaha yang melakukan kegiatan pembiayaan dalam bentuk pembelian dan atau pengalihan serta pengurusan piutang dan tagihan jangka pendek suatu perusahaan dari transaksi perdagangan dalam/luar negeri.

\section{TINJAUAN PUSTAKA}

\subsection{Akuntansi}

Akuntansi sangat erat kaitannya dengan informasi keuangan. Di samping itu, pengertian akuntansi juga berubah sesuai dengan perkembangan jaman dan teknologi. Menurut Reeve et al, mengatakan bahwa secara umum, akuntansi (accounting) dapat diartikan sebagai sistem informasi yang menyediakan laporan keuangan untuk para pemangku kepentingan mengenai aktiva ekonomi dan kondisi perusahaan. Pengertian akuntansi oleh Amerika Institute of Certified Public Accountants (AICPAI), akuntansi adalah suatu kegiatan jasa, fungsinya adalah menyediakan data kuantitatif, terutama yang mempunyai sifat dari kesatuan usaha ekonomi yang dapat digunakan dalam pengambilan keputusan-keputusan dalam memilih alternatif-alternatif dari suatu keadaan atau dapat dikatakan: Akuntansi adalah proses pencatatan, penggolongan, peringkasan dan penyajian secara sistematis dari transaksi-transaksi keuangan suatu badan usaha, serta penafsiran terhadap hasilnya.

\subsection{Akuntansi Keuangan}

Laporan keuangan yang dihasilkan dari akuntansi keuangan berupa laporan keuangan untuk tujuan umum (general purpose financial statement). Laporan keuangan bertujuan umum adalah laporan keuangan yang ditujukan untuk memenuhi kebutuhan bersama sebagian besar laporan pengguna laporan. Laporan keuangan untuk tujuan umum disusun berdasarkan data dan informasi yang telah terjadi sehingga lebih berorientasi pada data historis.

\subsection{Pengertian Aktiva Tetap}

Menurut PSAK No. 16 "Aktiva Tetap adalah aktiva berwujud yang diperoleh dalam bentuk siap pakai atau dengan dibangun terlebih dahulu yang digunakan dalam operasi perusahaan, tidak dimaksudkan untuk dijual dalam rangka kegiatan normal perusahaan dan mempunyai masa manfaat lebih dari satu tahun". sifat, yaitu;

Dari pengertian diatas dapat disimpulka bahwa suatu aktiva tetap mempunya beberapa

1. Masa manfaatnya jangka panjang atau lebih dari satu tahun 
2. Dimiliki dan digunakan dalam operasi normal perusahaan untuk menghasilkan barang atau jasa

3. Tidak ditujukan untuk dijual kembali atau diperdagangkan untuk mendapatkan keuntungan dari penjualan aktiva tersebut.

\subsection{Penyusutan Aktiva Tetap}

Penyusutan adalah alokasi jumlah suatu aktiva yang dapat disusutkan sepanjang masa manfaat yang diestmasi. Besarnya penyusutan untuk periode akuntansi dibebankan ke pendapatan baik secara langsung maupun tidak langsung.

Penyusutan untuk periode akuntansi dibebankan ke pendapatan langsung maupun tidak langsung. Aktiva yang dapat disusutkan adalah aktiva yang:

1. Diharapkan untuk digunakan selama lebih dari satu periode akuntansi, dan

2. Memiliki suatu masa manfaat yang terbatas; dan

3. dittahan oleh suatu perusahaan untuk digunakan dalam produksi atau memasok barang dan jasa, untuk disewakan atau untuk tujuan administrasi.

\subsection{Pengertian Sewa Menurut PSAK No. 30}

Pengerian Akuntan Indonesia (IAI) dalam pernyataan Standar Akuntansi Keuangan (PSAK) No. 30 (2011:30.25-29). Sewa adalah suatu perjanjian dimana pihak yang menyewakan (lessor) memberikan hak kepada penyewa (lessee) untuk menggunakan suatu aset selama periode waktu yang disepakati dengan biaya sewa (rent).

\section{- $\quad$ Klasifikasi Sewa}

Untuk tujuan akuntansi, PSAK 30 membagi sewa ke dalam dua kategori utama:

- $\quad$ Sewa Operasi, dan

- Sewa Pembiayaan.

Klasifikasi sewa yang digunakan dalam PSAK 30 ini didasarkan atas sejauh mana resiko dan manfaat yang terkait dengan kepemilikkan asset sewaaan berada pada lessor dan lessee. Risiko termasuk kemungkinana rugi dari kapasitas tidak terpakai (idle capacity) atau keusangan teknologi dan variasi imbal hasil karena perubahan kondisi ekonomi.

a. Sewa Operasi

Pendapatan sewa dari sewa operasi diakui seabagai pendapatan dengan dasar garis lurus selama masa sewa, kecuali terdapat dasar sistematis lain yang lebih mencerminkan pola waktu dimana manfaat penggunaan aset sewaan menurun.

Pengungkapan:

- Jumlah agregat pembayaran sewa minimum di masa depan dalam sewa operasi yang tidak dapat dibatalkan untuk setiap periode

- Total rentla kontinjen yang diakui sebagai penghasilan dalam periode berjalan.

b. Sewa Pembiayaan

Pengakuan awal: Dalam sewa pembiayaan, lessor mengakui aset berupa piutang sewa pembiayaan di laporan posisi keuangan sebesar jumlah yang sama dengan investasi sewa neto tersebut.

Pengungkapan:

- Rekonsiliasi antara investasi sewa bruto dan nilai kini piutang pembayaran sewa minimum pada tanggal pelaporan.

- Penghasilan pembiayaan tangguhan

- Nilai residu tidak dijamin sebagai manfaat lessor

- Akumulasi penyisihan piutang tidak tertagih atas pembayaran sewa minimum

- Rental kontinjen yang diakui sebagai penghasilan dalam periode berjalan.

PSAK 30 tidak mengatur tentang konsep 'mengalihkan secara substansial seluruh risiko dan manfaat yang terkait dengan kepemilikan'. Namu, PSAK 30 memang memberikan contoh situasi yang mengarah pada sewa yang diklsifikasikan sebagai sewa pembiayaan sebagai berikut: 
- $\quad$ Sewa mengalihkan kepemilikan asset kepada lessee pada akhir masa sewa.

- $\quad$ Sewa mengandung opsi pembelian asset.

- $\quad$ Masa sewa adalah untuk sebagian besar umur ekonomis asset.

- Nilai kini dari jumlah pembayaran sewa minimum (tidak termasuk biaya pelaksanaan) secara substansial mendekati nilai wajar asset sewaan.

- $\quad$ Aset sewaan bersifat khusus sehingga hanya lessee yang dapat menggunakannya tanpa perlu modifikasi secara material.

PSAK 30 lebih jauh menyebutkan indicator dari situasi yang secara individual atau gabungan dapat juga menunjukkan bahwa sewa diklasifikasikan sebagai sewa pembiayaan.

- Jika lessee dapat membatalkan sewa, maka rugi lessor yang terkait dengan pembatalan ditanggung oleh lessee;

- $\quad$ Laba atau rugi dari fluktuasi nilai wajar nilai residu dibebankan kepada lessee; dan

- $\quad$ Lessee memiliki kemampuan untuk melanjutkan sewa untuk periode kedua dengan nilai rental yang secara substansial lebih rendah dari nilai pasar rental.

\subsection{Sewa Guna Usaha}

Leasing ialah setiap kegiatan pembiayaan perusahaan dalam bentuk penyediaan barang-barang modal untuk digunakan oleh suatu perusahaan untuk suatu jangka waktu tertentu berdasarkan pembayaran-pembayaran secara berkala disertai dengan hak pilih (opsi) bagi perusahaan tersebut untuk membeli barang-barang modal yang bersangkutan atau memperpanjang jangka panjang leasing berdasarkan nilai sisa yang telah disepakati bersama.

\section{- Jenis-jenis Sewa Guna Usaha (Leasing)}

- $\quad$ Capital lease atau Capital lease (Sewa guna usaha dengan hak opsi)

Pada transaksi leasing jenis ini lessee yang membutuhkan barang menentukan barang sendiri. jenis serta spesifikasi barang yang dibutuhkan. Lesse juga mengadakan negosiasi dengan supplier mengenai harga, syarat-syarat perawatan serta lain-lain hal yang berhubungan dengan pengoperasian barang tersebut.Kemudian Lessor akan mengeluarkan dananya untuk membayar tersebut kepada supplier dan setelah itu barang tersebut diserahkan kepada lessee. Sebagai imbalan atas jasa penggunaan barang tersebut maka lessee akan membayar secara berkala kepada lessor sejumlah uang untuk jangka waktu tertentu yang telah disepakati bersama. Pada akhir masa lease, lessee mempunyai hak pilih untuk membeli barang tersebut sebagai nilai sisanya, mengembalikan barang tersebut kepada lessor atau juga mengadakan perjanjian leasing lagi untuk tahap yang kedua atas barang yang sama

- $\quad$ Operating Lease (Sewa guna usaha tanpa hak opsi)

Pada transaksi leasing jenis ini, lessor membeli barang dan kemudian menyewakannya kepada lessee untuk jangka waktu tertentu. Pada prakteknya lessee membayar uang secara berkala yang besarnya secara keseluruhan tidak meliputi harga barang serta biaya yang telah dikeluarkan oleh lessor.Disini secara jelas tidak ditentukan adanya nilai sisa serta hak opsi bagi lessee. Setelah masa lease berakhir, lessor merundingkan kemudian dilakukannya kontrak lease yang baru dengan lesse yang sama atau juga lessor mencari calon lessee yang baru.Pada operating lease ini biasanya lessor bertanggung jawab mengenai perawatan barang tersebut. Barang-barang yang sering digunakan dalam operating lease ini biasanya barang-barang mempunyai nilai tinggi seperti alat-alat berat, traktor, mesin-mesin, dan sebagainya.

\section{- Kriteria Penggolongan Sewa Guna Usaha}

a. Penyewa guna usaha (lessee)

b. Pembayaran Berskala

c. Masa sewa guna usaha minimum 2 (dua) tahun

d. Jumlah pembayaran sewa guna usaha

e. Masa sewa guna usaha ditetapkan 
f. Perjanjian sewa guna usaha

\subsection{Akuntansi Untuk Lease}

Menurut Standar Akuntansi Keuangan (2012) Lease yaitu suatu perjanjian kontrak yang mengalihkan hak untuk menggunakan aktiva dalam periode waktu yang ditentukan.

- $\quad$ Keunggulan Leasing Dari Segi Ekonomi

a. Tanpa ada uang muka (no down payment)

b. Menghindari resiko pemilikan (avoids risks of ownership)

c. Flexibility

- $\quad$ Operating Lease-Lessor

a. Barang Modal yang disewa guna usahakan dilaporkan berdasarkan harga perolehan setelah dikurangi akumulasi penyusutannya.

b. Aktiva yang disewa guna usahakan dilaporkan secara terpisah dari aktiva tetap yang tidak disewa guna usahakan.

c. Perhitungan rugi laba harus disusun sedemikian rupa sehingga seluruh pendapatan dilaporkan dalam kelompok yang terpisah dari kelompok biaya.

d. Penyusutan aktiva yang disewa guna usaha harus dilaporkan secara terpisah dari aktiva yang tidak disewa guna usahakan.

- Capital lease-lessee

a. Aktiva yang disewa guna usakan dilaporkan sebagai bagian aktiva tetap dalam kelompok sendiri. kewajiban sewa guna usaha harus disajikan terpisah dari kewajiban lainnya.

b. Pengungkapan yang layak harus dicantunkan dalam catatan atas laporan keuangan

\section{8}

\section{Pelaporan Dan Pengungkapan Transaksi Capital Lease}

Pelaporan akuntansi capital lease oleh penyewa guna usaha menurut PSAK No. 30 adalah: Aktiva yang disewa guna usahakan dilaporkan sebagai bagian aktiva tetap dalam kelompok tersendiri.Pengungkapan yang layak harus dicantumkan dalam catatan atas laporan keuangan mengenai hal-hal sebagai berikut:

1. Jumlah pembayaran sewa guna usahakan yang paling tidak untuk dua tahun berikutnya.

2. Penyusutan aktiva yang disewa guna usahakan yang dibebankan dalam tahun berjalan.

3. Jaminan yang diberikan sehubungan dengan transaksi sewa guna usaha.

4. Keuntungan atau kerugian yang ditangguhkan beserta amortisasinya sehubungan dengan transaksi penjualan dan penyewaan kembali (sale and leasebacak). Ikatan-ikatan penting yang dipersyaratkan dalam perjanjian sewa guna usaha.

\subsection{Pelaporan dan pengungkapan transaksi operating lease}

Menurut PSAK No.30 bahwa pengungkapan yang layak harus dicantumkan atas laporan keuangan mengenai:

a. Jumlah Pembayaran sewa guna selama tahun berjalan yang dibebankan sebagai biaya sewa.

b. Jumlah pembayaran sewa guna usaha yang harus dilakukan paling tidak 2 tahun berikutnya.

c. Jaminan yang diberikan sehubungan dengan transaksi sewa guna usaha.

d. Keuntungan atau kerugian yang ditangguhkan beserta amortisasinya sehubungan dengan transaksi sale and lease back.

f. Ikatan-ikatan penting yang dipersyaratkan dalam perjanjian sewa guna usaha (major covenants). 


\section{METODE PENELITIAN}

\subsection{Jenis dan sumber data}

Dalam penelitian ini menggunakan metode penelitian Deskriptif kualitatif, karena dalam mengkaji permasalahan, penelitian tidak membuktikan ataupun menolak hipotesis yang dibuat sebelum penelitian tetapi mengolah data dan menganalisis suatu masalah secara non numerik. Metode Kualitatif untuk menguji hipotesis atau teori. Dalam penyusunan skripsi ini penulis menggunakan data sekunder yaitu data yang diperoleh langsung dari objek penelitian dalam halini pada Astra Credit Companaise di Manado dalam kurun waktu Tahun 2013 dan 2014.

\subsection{TeknikPengumpulan Data}

Teknik Pengumpulan data menggunakan beberapa cara yaitu:

1. Teknik Wawancara, yaitu melakukan Tanya jawab secara langsung dengan pihak-pihak yang terkait dengan pokok permasalahan untuk mendapatkan keterangan yang dibutuhkan terutama yang berhubungan dengan pencatatan, penyususnan, dan penyajian laporan keuangan. Sesuai dengan jenisnya, penulis memakai jenis wawancara.

2. Teknik observasi, yaitu melakukan pengamatan langsung terhadap penerapan akuntansi khususnya akuntansi leasing pada Astra Credit Companaise seperti mempelajari dokumen dokumen perjanjian sewa, buku jurnal yang mencatat transaksi yang dilakukan perusahaan, laporan keuangan (neraca dan laporan laba rugi) selama periode sewa, formulir dan catatan lain yang berhubungan dengan perkembangan atas topik yang di bahas.

\subsection{MetodeAnalisis}

Adapun metode analisis yang digunakan untuk membahas permasalahan dalam penelitian ini adalah:

1. Menganalisis data-data yang digunakan sehubungan dengan pencatatan Leasing.

2. Menganalisi pencatatan akuntansi leasing dan pelaporannya yang tepat atau transaksi tersebut.

3. Menarik Kesimpulan dan saran.

\section{HASIL ANALISIS DAN PEMBAHASAN}

\subsection{Hasil analisis}

1. Pembiayaan Konsumen Pada Astra Credit Companies

Astra Credit Companies, dalam melaksanakan kegiatan pembiayaan atas barang modal mengenal jenis sewa yaitu vendor lease. Vendor Program atau disebut juga Vendor lease adalah suatu metode penjualan yang dilakukan oleh produsen atau dealer dimana perusahaan pembiayaan memberikan atau menyediakan fasilitas pembiayaan kepada pembeli barang.

2. Pihak-pihak Yang Terkait

Dalam PSAK No. 30 tentang sewa, pihak-pihak yang terlibat dalam perjanjian sewa adalah lessee dan lessor. Pada Astra Credit Companaies yang menjalankan kegiatan pembiayaan selain melibatkan lesse dan lessor, juga melibatkan dealer atau supplier yang menyediakan barang modal atas biaya dari lessor. Yang menjadi supplier adalah Hasjrat Abadi Toyota, Astra Daihatsu, Astra isuzu, serta Honda dan Nissan.

3. Ketentuan dan Dokumen yang dipergunakan dalam Kontrak Sewa

ACC mencatat setiap transaksi oleh bagian marketing sesuai dengan substansi dan keadaan keuangan yang ada dalam perusahaan. Ketentuan -ketentuan dasar selanjutnya berhubungan dengan transaksi dalam perusahaan dapat diatur berdasarkan rapat direksi perusahaan dan peraturan yang ada, yang merupakan kebijakan perusahaan yang harus dipatuhi diantara kedua pihak baik lessee maupun lessor juga supplier. 
4. Pencatatan pihak lessor

Pencatatan yang dilakukan oleh ACC yang pada saat perusahaan melakukan pembayaran kepada dealer maka transaksi tersebut dicatat di sebelah debit didalam buku besar, Karena perusahaan mengeluarkan saldo untuk pembiayaan ke pabrik sesuai dengan transaksi. Pada saat lesse melakukan pembayaran angsuran pertama, Piutang sewa dan pendapatan administrasi dicatat disebelah kredit dalam buku besar, sehingga saldo dalam kas berkurang dan piutang berambah.

5. Laporan keuangan ACC

laporan keuangan ACC, seringkali mengeluarkan biaya langsung awal seperti komisi, biaya legal, dan biaya internal yang telah di distribusikan langsung dengan proses negosiasi dan aturan-aturan tentang sewa.pihak perusahaan juga melibatkan lessor atau dealer, Maka biaya langsung awal juga dipehitungkan sebagai bagian dari pengakuan awal piutang sewa pembiayaan dengan mengurangi penghasilan yang diakui selama masa sewa. biaya yang dikeluarkan oleh lessor atau dealer yang terkait dengan negosiasi tidak termasuk biaya langsung awal.

\subsection{Pembahasan}

Astra Credit Companaies adalah perusahaan pembiayaan mobil dan alat berat yang mengalihkan secara substansial seluruh risiko dan manfaat yang terkait dengan kepemilikan suatu aset. Hak milik pada akhirnya dapat dialihkan, dapat juga tidak dialihkan Astra Credit Companaies juga adalah perusahaan pembiayaan yang membeli barang modal dan selanjutnya disewakan kepada penyewa. Penerapan PSAK No. 30 pada Astra Credit Companaies disesuaikan dengan jenis dan golongan sewa. Kegiatan yang berjalan mekanisme sewa di Astra Credit Companaies harus diikuti oleh pihak lessee dan lessor sesuai dengan peraturan yang berlaku berdasarkan hasil rapat dewan pimpinan perusahaan.

Lessee, Lessor, juga dealer adalah salah satu persyaratan dan ciri-ciri yang harus dimiliki oleh setiap perusahaan pembiayaan Hasjrat Abadi Toyota, Astra Daihatsu, Astra Isuzu, serta Honda dan Nissan sebagai dealer yang meyediakan fasilitas pembiayaan sangat bekerja sama baik dengan Astra Credit Companaise dalam melakukan kegiatan pembiayaan kepada konsumen. Dan berdasrkan hasil penelitian, secara umum konsumen yang mengajukkan kerja diperhitungkan sebagai bagian dari pengakuan awal piutang sewa pembiayaan dan mengurangi penghasilan yang diakui selama masa sewa.

Dalam melaksanakan kegiatan pembiayaannya Astra Credit Companaies menggunakan dokumen pokok dan dokumen penunjnag dalam melaksanakan pembiayaan. Dokumen penunjang yang harus disiapkan oleh calon konsumen berupa beberapa okumen yang menjadi ketentuan dan aturan yang diberlakukan oleh perusahaan. Konsumen harus dapat melengkapi dokumen-dokumen yang telah ditetapkan oleh perusahaan sehingga permohonan untuk pembiayaan pada Astra Credit Companaies adalah dengan dibuatnya surat perjanjian tertulis antara lessor dan lessee agar terjadi kesepakatan antara kedua belah pihak dalam pelaksanaan kegiatan pembiayaan ini.

Proses pencatatan yang ada di Astra Credit Companies pada dasarnya telah sesuai dengan teori yang ada da sesuai dengan PSAK No. 30 tentang sewa. Ayat jurnal yang dipakai dimulai dari proses pengakuan dan pencatatan sudah sesuai dengan teori. Dimana seluruh piutang, dan pendapatan dicatat disebelah kredit sehingga saldo berkurang. Untuk akun bunga sewa juga tercatat sebelah kredit, begitu juga dengan hutang PPN.

Penyusunan laporan keuangan pada Astra Credit Companies sudah dilaksanakan sesuai dengan pernyataan Stanr Akuntansi Keuangan yang ada. Dalan laporan keuangan Astra Credit Companise biaya langsung awal seperti komisi, biaya legal dan biaya internal distribusikan langsung dengan proses negosiasi dan aturan-aturan tentang sewa. Biaya 
langsung awal diperhitungkan sebagai bagian dari pengakuan awal piutang sewa pembiayaan dan mengurangi penghasilan yang diakui selama masa sewa.

Penerapan PSAK No. 30 sangat dibutuhkan dalam suatu perusahaan sewa karena dapat dijadikan pedoman terutama oleh bagian akuntansi dalam pembuatan dan penyelesaian laporan keuangan.

Pelaporan akuntansi leasing dan pelaporan pada ACC yaitu:

Penjualan Kendaraan sebagai berikut:

Kas

XXX

Piutang pembiayaan konsumen

$\mathrm{XXX}$

Selanjutnya untuk mencatat PPN sebagai berikut:

Kas

PPN

$\mathrm{XXX}$

$\mathrm{XXX}$

Piutang Pembiayaan Konsumen

$\mathrm{XXX}$

Sedangkan untuk pembayaran DP pencatatan jurnal sebagai berikut: Kas

XXX

DP Piutang Pembiayaan Konsumen

$\mathrm{XXX}$

Untuk Penerimaan Pembayaran angsuran Kredit dicatat: Kas

Biaya bunga leasing

$\mathrm{XXX}$

Piutang Pembiayaan Konsumen

$\mathrm{XXX}$

$\mathrm{XXX}$

Untuk Jurnal amortisasi pendapatan

Piutang pembiayaan konsumen $\quad$ xxx

Keuntungan/kerugian dari penurunan nilai $\quad \mathrm{xxx}$

Untuk pengalihan kepemilikan kendaraan di akhir periode Kas

$\mathrm{XXX}$

Piutang pembiayaan konsumen

Biaya bunga leasing

$\mathrm{XXX}$

Akumulasi penyusutan aktiva pembiayaan

$\mathrm{XXX}$

Setiap transaksi dicatat, dan pengakuan pada akhir periode leasing adanya pengalihan kepemilikan juga dicatat. Hal ini merupakan ukurans bahwa ACC menganut Capital Lease dimana sewa guna usaha ini dapat mengalihkan kepemilikan pada akhir masa sewa.

\section{KESIMPULAN DAN SARAN}

\subsection{Kesimpulan}

Berdasarkan hasil penelitian dan pembahasan yang telah disajikan pada bab-bab terdahulu maka dapat disimpulkan bahwa untuk pengakuan awal pada perusahaan sesuai dengan hasil analisis yang dipelajari. Seperti biaya langsung awal, diperhitungkan sebagai bagian dari pengakuan awal piutang sewa pembiayaan dan mengurangi penghasilan yang diakui selama masa sewa. Untuk pengukuran pada perusahaan juga telah sesuai dengan hasil dan analisis yang dipelajari. Perusahaan mengakui investasi sewa bruto dan mengakui adanya piutang yang dicatat pada tanggal pelaporan yang sama. Perusahaan tidak mencatat nilai residu tidak dijamin sebagai manfaat perusahaan (lessor) Penerapan sewa pada Astra Credit Companies telah sesuai dengan teori-teori tentang sewa dan pernyataan-pernyataan yang terdapat dalam Pernyataan Standar Akutansi Keuangan (PSAK) No. 30 tentang sewa. Mulai dari proses pengakuan awal, pengukuran setelah pengakuan awal, dan pengungkapan. Semua ketentuan dan aturan yang berlaku atas kesepakatan bersama antara lesse, lessor, dan dealer tentunya telah didasari atas PSAK No 30. 


\subsection{Saran}

Adapun saran yang dari hasil penelitian ini adalah :

1. Astra Credit Companies sebaiknya melakukan pemisahan pencatatan penyusutan aktiva tetap dengan aktiva yang disewa gunakan, sesuai dengan PSAK 30.

2. Astra Credit Companies sebaiknya selalu mengikuti perkembangan peraturan pelaporan yang terkait dengan transaksi leasing.

\section{DAFTAR PUSTAKA}

Abdulah \& Francis Tantri, 2012, "Teori Akuntansi”, Buku Satu, Edisi Kelima, Penerbit Interaksar, Jakarta

Ahmad Riahi \& Belkaoui, 2011, "Teori Akuntansi”, Buku Dua, Edisi Kelima, Penerbit Salemba Empat.

Ikatan Akuntansi Indonesia. 2011. Standar Akuntansi Keuangan No. 30 tentang Sewa, Jakarta.

Iksan Setiawan. 2015. Analisis penerapan akuntansi leasing pada PT Federal internasional finance Manado

Irene Herminda Runtuwene, 2013. Penerapan akuntansi piutang leasing untuk perencanaan dan pengendalian pada PT. Suzuki finance Indonesia cabang manado.

Kuncoro.M.2011. Metode kuantitatif (Teori dan Aplikasi Untuk Bisnis dan Ekonomi. UP UMP YKPN, Jakarta.

Martani D, dkk. 2012, “Akuntansi Keuangan Menengah Berbasis PSAK”, Buku 1, Penerbit Salemba Empat, Jakarta.

Rina yanti, 2014. Analisis akuntansi leasing pada PT. Puri green resources pekanbaru.

Soekadi, 2010. jenis-jenis sewa guna usaha (leasing).Grava Media, Yogyakarta

Suwardi,SE.M,SI,AK. Standar Akuntansi Keuangan (PSAK) No.30 (2011:30.25-29). 